Article

\title{
Structural Equation Model for Burn Severity with Topographic Variables and Susceptible Forest Cover
}

\author{
Eujin-Julia Kim ${ }^{1}$ (D) and Sang-Woo Lee ${ }^{2, *}$ \\ 1 Department of Landscape Architecture, Gangneung-Wonju National University, Gangneung-si 25457, Korea; \\ ejkim@gwnu.ac.kr \\ 2 Department of Forestry and Landscape Architecture, Konkuk University, Gwangjin-gu, Seoul 05029, Korea \\ * Correspondence: sw17311@konkuk.ac.kr
}

Received: 9 May 2018; Accepted: 12 July 2018; Published: 15 July 2018

check for updates

\begin{abstract}
Due to its significant roles in post-fire responses of forest ecosystem, numerous studies have been investigating factors affecting burn severity. In the broad sense, topography, fuels, and fire weather, known as the forest fire triangle, determine the degree of burn severity. Most previous studies have adopted ordinary least squares (OLS) methods to investigate these factors, which have proven effective for capturing the direct and linear effects of those variables on burn severity. However, they oversimplify the relationships among variables and have limitations in explaining the complex effects of the variables. One way to overcome this limitation is the structural equation model (SEM) method. SEM can decompose effects of a variable into direct effects and indirect (i.e., acting through other variables) effects. The goal of this study is to capture a systematic structure, explaining how topographic characteristics including slope, elevation, topographic wetness index (TWI), solar radiation index (SRI), and susceptible forest cover type (i.e., Japanese red pine) affect burn severity. We built a hypothetical SEM and estimated the model in AMOS. The results strongly suggest that the effects of topographic characteristics are far more complex than those suggested by the OLS analyses in previous studies. Specifically, elevation and TWI had direct and indirect negative effects on burn severity, while slope and SRI had only an indirect positive effect, which was not captured in the linear regression model. Nonetheless, the percentage of red pine showed the strongest positive effect on burn severity (i.e., increasing burn severity). The results of this study and those of previous studies reinforce the importance of controlling susceptible forest cover through forest management and silviculture.
\end{abstract}

Keywords: structural equation model; burn severity; TWI; SRI; Japanese red pine; topography; path analysis; AMOS

\section{Introduction}

Forest fires create a unique mosaic of burn severity that has considerable impact on post-fire biotic and abiotic characteristics and on the dynamics and complexity of the forest ecosystem at various spatial and temporal scales [1-4]. In the forest fire literature, burn severity has been shown to be strongly associated with avian and small mammal responses [5], soil properties [6,7], species diversity [8], net forest primary production [9], seed germination [10,11], landscape heterogeneity [11-14], tree mortality [15,16], and tree regeneration and responses [7,17-21]. Thus, effective fire-resilient forest management and restoration of burned areas must be practiced on the basis of a clear understanding of how burn severity is determined by various environmental variables.

However, the roles of environmental variables in determining the burn severity of a fire event are poorly understood, in part due to the spatially varying and non-linear effects of environmental variables on burn severity $[22,23]$ and the dynamics and complexity of environmental interactions. 
From this time forward, it can no longer be excusable that our understanding of the relationships of environmental variables with burn severity is far from their true nature.

Burn severity is determined largely by weather, fuel, and topography (known as the forest fire triangle). The primary characteristics of topography that affect burn severity, as described in previous studies, include elevation, slope, aspect, topographic position, solar radiation, and topographic wetness [22-25]. In the fire literature, weather is described as having two aspects, climate and fire weather. Climate reflects long-term precipitation, temperature, relative moisture, solar radiation, drought, and wind at a broad temporal and spatial scale, whereas fire weather is associated with site-specific weather conditions during a burning event [26-28]. Many previous studies have reported that fuel is the key component in determining burn severity, and some examples of critical characteristics of fuels affecting burn severity include fuel type, tree density, fuel moisture, and spatial distribution and heterogeneity of fuel $[4,20,25]$. When evaluating the relationships of environmental variables with burn severity, most previous studies have investigated simple, linear, and stationary relationships, which may not be sufficient to delineate the complex nature of the relationships. Recently, Lee et al. [22] reported that the relationship between susceptible tree cover and burn severity might not be constant over space (i.e., non-stationary effects). In their study, they estimated a conventional regression model (i.e., stationary model) and a geographically weighted regression model (i.e., non-stationary model) for burn severity with Japanese red pine trees and compared their performance in predicting burn severity. The comparison of the two models clearly indicated that the non-stationary model explained the variance of burn severity much better than the conventional regression, suggesting spatially varying effects of red pine trees on burn severity. Similarly, Lee et al. [23] demonstrated that there might be non-linear relationships between topographic variables and burn severity, while red pine trees showed a linear relationship with burn severity. Nelson [29] also reported non-linear effects of weather characteristics on burn severity. The results of these recent studies provide an interesting glimpse into the complex relationships between environmental variables and burn severity, but a large portion of such complex relationships remain unclear.

This study aimed to investigate structural relationships of topographic characteristics and red pine trees with burn severity. Aside from spatially varying effects of susceptible fuels and non-linear effects of topographic characteristics, some of the complex relationships between topographic characteristics and burn severity might be associated with indirect effects of topographic characteristics on burn severity through susceptible fuel (i.e., Japanese red pine trees). Direct effects of topographic characteristics are site-specific topographic circumstances during a fire event. Meanwhile, indirect effect can be considered as pre-fire, long-term conditions resulting from cumulative interactions among topographic characteristics and red pine trees over time. The results of this study might fill some gaps of our knowledge on the true nature of burn severity ensuing from complex interactions of environmental variables and fuels.

\section{Materials and Methods}

\subsection{Samcheok Fire}

In April 2000, the Samcheok fire $\left(37^{\circ} 7^{\prime} 42^{\prime \prime}-37^{\circ} 20^{\prime} 34^{\prime \prime} \mathrm{N}, 129^{\circ} 11^{\prime} 24^{\prime \prime}-129^{\circ} 22^{\prime} 32^{\prime \prime}\right.$ E) started from a garbage burn site and eventually burned about 16,151 ha of red pine-dominated forests for nine consecutive days in Samcheok Province, Korea (Figure 1). The fire, which was recorded as the largest forest fire in Korea since 1960 [30], resulted in a unique burn mosaic over space. A number of studies identified topographic complexity and highly heterogeneous spatial distributions of red pine trees (Pinus densiflora), which is known to be the most susceptible tree in Korea (e.g., [20,22,23]) due to heavy crown fuel load and highly flammable needles containing high concentrations of essential oils [21]. The pre-fire forest was dominated by Japanese red pine (Pinus densiflora Siebold and Zucc.) (Figure 1). Other tree stands occupying the area included Korean white pine (Pinus koraiensis Siebold and Zucc.), mixed forests, Mongolian oak (Quercus mongolica Fisch. ex Ledeb.), larch (Larix leptolepis Gordon), and 
Japanese alder (Alnus japonica (Thunb.) Steud) [30]. According to the Korean Forest Services, high wind speed $(26.8 \mathrm{~m} / \mathrm{s})$ and low relative humidity $(7 \%)$ during the fire increased burn severity and fire spread [30].

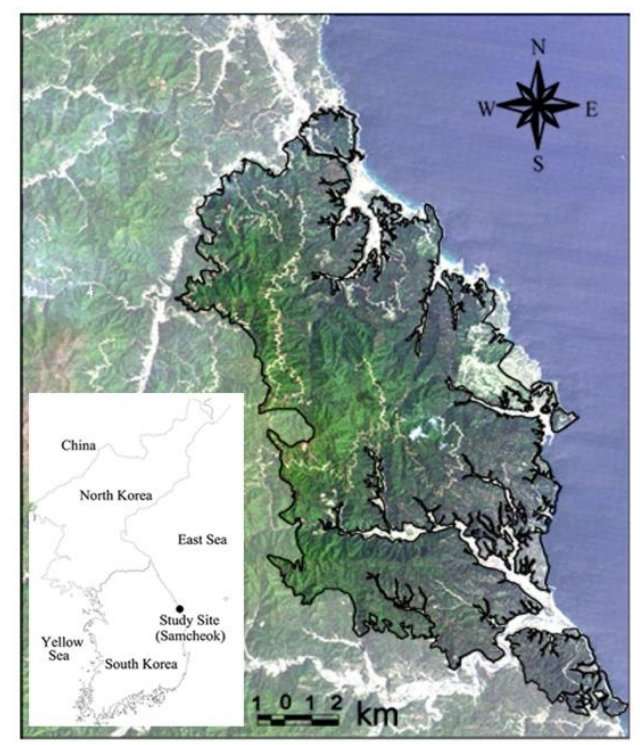

(a) Pre-fire (1999)

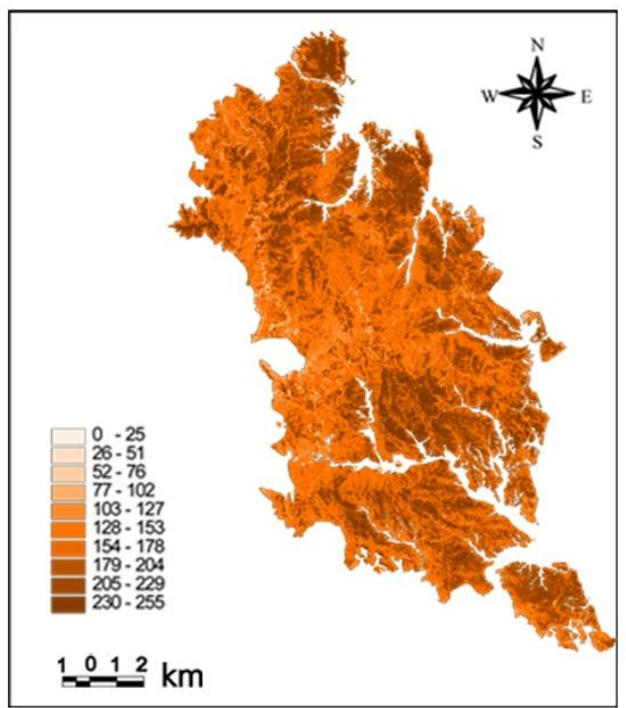

(c) dNBR

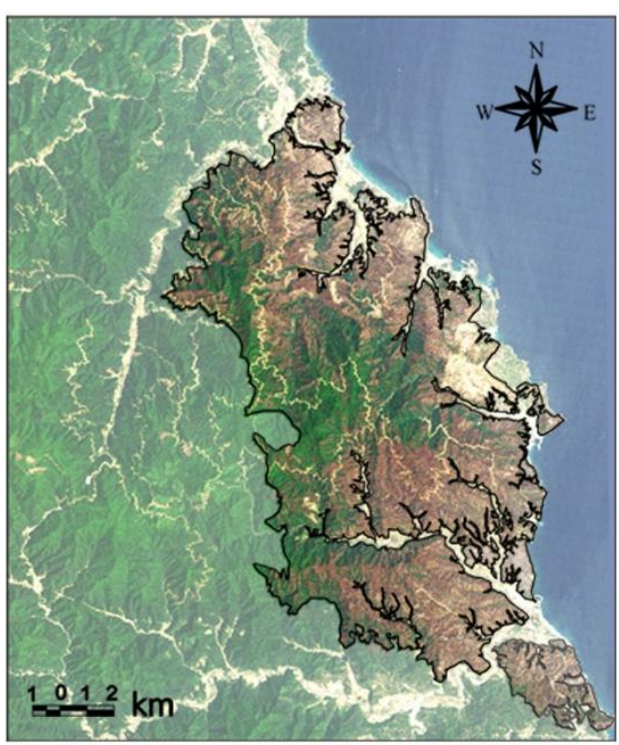

(b) Post-fire (2000)

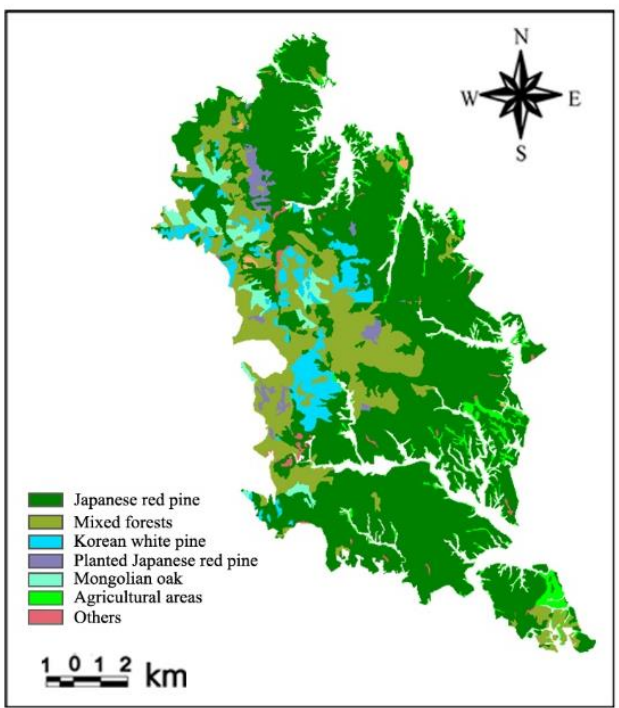

(d) Forest cover type

Figure 1. Site of Samcheok fire (key map), pre-fire image acquired in 1999 (a), post-fire image acquired in 2000 (b), and delta normalized burn ratio (dNBR) map (c). The pre-fire forest was dominated by Japanese red pine (d). About 16,151 ha of densely forested area burned for nine consecutive days. The dNBR map clearly shows that areas in the southeast were burned more severely.

In preliminary analysis, burn severity in the study areas significantly correlated with Japanese red pine $(r=0.58)$ and mixed forest $(r=-0.25)$, while significant correlations were not observed between burn severity and Mongolian oak, Korean white pine, larch, Japanese alder and agricultural areas. The preliminary analysis clearly showed that Japanese red pine forest cover was the most susceptible forest cover the study areas. 


\subsection{Unit for Spatial Analysis}

For the spatial analysis, we generated 802 grid cells $(500 \mathrm{~m})$ over the study areas using Autodesk Computer-aided Drafting (CAD) software version 2014 (Autodesk Inc., San Rafael, CA, US). The grid CAD file was converted into a geographic information system (GIS) file with 802 polygons and a unique identification code (ID) was assigned to each grid cell polygon. Multiple digital maps for burn severity, red pine trees, elevation, slope, solar radiation index (SRI), and topographic wetness index (TWI) were derived from multiple sources. The digital maps were converted into GRID format in the GIS, and then the mean values of all selected variables within each grid cell polygon were computed using the overlay function in GIS.

Unit of analysis $(500 \mathrm{~m})$ was determined with consideration on the largest data resolution. We extracted dataset for analysis from multiple sources such as National Forest Classification Digital Map (NFCDM, no resolution) to compute the percent of susceptible forest cover, LandSat images (30 m resolution) to generate burn severity and DEM ( $50 \mathrm{~m}$ resolution) to capture topographic characteristics. Thus, we had to determine analysis resolution based on the resolution of DEM (50 m resolution). Since there was no clear-cut criteria in determining the analysis resolution with the largest data resolution, we rationalized that analysis resolution had to be 10 times greater than the resolution of DEM to capture the topographic characteristics (i.e., SRI, TWI). In addition, the spatial unit (i.e., size of the grid cell polygon, $500 \mathrm{~m}$ ) has been shown to be effective for capturing complex topographic characteristics in the study areas $[22,23,25]$.

\subsection{Delineating Topography and Distribution of Red Pine Trees}

As one part of the forest fire triangle, topographic characteristics have been shown to have significant impacts on fire behavior. In the fire literature, numerous indictors have been proposed to delineate topographic characteristics, effects of solar radiation on fuels, and spatial distributions of forest cover types in the relationships of topographic characteristics with fire behavior. Some popular topographic indicators implemented in the fire literatures are elevation, slope, aspect, TWI, SRI, topographic position index, elevation relief ratio, heat load index, topographic roughness index, and gullies (e.g., [20,22,23,31-35]). Despite the fact that each topographic indicator has its own advantages in delineating topographic characteristics, we prefer simple indicators because it is easy to understand study results and implement these into practice in forest management and silviculture for managers and public officers. Another consideration is multicollinearity problems among indicators. According to Lee et al. [23], most topographic indicators tend to be highly correlated, which could lead to low model performance.

Based on these considerations, we selected elevation $(\mathrm{m})$, slope $\left({ }^{\circ}\right)$, TWI, and SRI to delineate topographic characteristics in this study. Elevation and slope are the simplest measurements and have been implemented in numerous previous studies to describe topographic characteristics (e.g., [22,23,36-38]). SRI is a measure of the potential annual direct incident solar radiation at specific location [39]. TWI is a measure of the availability of long-term soil moisture as affected by local slope and drainage [40,41]. All topographic variables were computed with Digital Elevation Model (DEM, $50 \mathrm{~m}$ resolution), released by Korean Geographic Survey.

The percentage of red pine tree cover within a grid cell was computed using the National Forest Classification Digital Map (NFCDM) released by the Korean Forest Service (KFS) in GIS Shape file format. On the basis of satellite imagery ( $25 \mathrm{~m}$ resolution) and field survey data $(1 / 25,000$ scale), the NFCDM classifies forest cover based on three criteria, tree type, age group, and sub-layer. Initially, the NFCDM identified 50 forest cover types, but we aggregated these into the 10 categories of including mixed coniferous forest, broad-leaved forest, mixed forest, planted Japanese red pine forest, planted Korean white pine forest, planted pitch pine forest, Japanese red pine forest, open forest, and agricultural land. A digital tree cover map containing only Japanese red pine tree cover was extracted from the aggregated forest cover map and converted into GRID format with $50 \mathrm{~m}$ resolution. Finally, 
the percentage of red pine trees within each grid cell was computed by overlaying the red pine tree map layer onto the grid cell layer in GIS.

\subsection{Mapping Burn Severity}

Many previous studies have measured burn severity by the vegetation consumed by fire. This study adopted the same approach and defined burn severity as the degree of change in vegetation. Consumption of vegetation by fire causes a remarkable reduction in visible to near-infrared reflectance that can be captured effectively by comparing pre-fire and post-fire satellite imagery. One of the most popular methods for comparing pre-fire reflectance with post-fir reflectance of vegetation is the delta normalized burn ratio (dNBR) (e.g., [8,22]; see [20] for more details on computing dNBR with multiple bands). A number of studies have reported better performance in delineating burn severity with dNBR than with other similar indexes (e.g., NDVI) (e.g., [42-45]), and it has been shown to be an effective tool for capturing burn severity in Korean forests (e.g., [22,23,25,45]). To compute dNBR, we used Landsat satellite images (30 m resolution) acquired in 1999 and 2000 and then calculated dNBR using the Erdas 10.3 service pack (Leica Geosystems, St. Gallen, Switzerland). The dNBR was then classified into six classes ranging from extreme severity to low severity to unburned using the Remote Sensing Application Center method [46]. Then, burn severity was validated with ground-measured composite burn index (CBI) values surveyed from 25 plots. The classified burn severity was transformed into GRID file format, and the mean burn severity in each grid cell polygon was computed in GIS using the overlay function. In a broad sense, Class 5 (very high severity) and Class 6 (extreme severity) are typified by nearly complete combustion of all litter, duff, and small logs, mortality of small trees, and consumption of large tree crowns while Class 2 (low severity) indicates that the fire consumes only light fuels including litters, small dead branches, or ground cover, together with scorching of the crowns of medium-sized trees [46].

\subsection{OLS and Hypothesized SEM}

Ordinary least squares (OLS) approaches (i.e., linear regression models) are the most common approaches used in forest fire studies investigating environmental factors affecting burn severity. However, although OLS can be useful for examining direct influences of environmental variables, especially effects of topography, fuels, and weather, on burn severity, it has limitations in revealing complex relationships between environmental variables and burn severity. Recent studies have reported that the effects of environmental variables on burn severity might not be linear or constant over space and time [22,23,47]. Because of the nature of environmental variables, they interact with each other [47-50], and their interactions over space and time can modify and sometimes amplify their effects on fire severity during a fire event. In such cases, the complex effects of environmental variables on burn severity may not be predicted by a simple OLS method. To understand the causal mechanisms better, structural equation models (SEM) can be useful tools for addressing complex sets of relationships between environmental variables and burn severity. Whereas linear regression estimates direct simple effects on burn severity, SEM specifies more complex systems of relationships of environmental variables with burn severity, focusing on both direct effects of environmental variables on burn severity and indirect effects on burn severity through other variables. The SEM approach has the advantage of yielding consistent and unbiased estimates of unknown model parameters and allowing the researcher to perform a global test of model fit. For SEM analysis, instead of using raw data, the variance and covariance matrix is used. The main idea of SEM is to compare the variance/covariance matrix of observed variables with an implied variance matrix, a simpler underlying structure, yielded by SEM. An important aspect of both OLS and SEM is estimating unknown parameters (regression coefficients and path coefficients); however, the methods of estimation are different. Unlike standard regression using OLS, the maximum likelihood (ML) method, which finds the maximum value of the joint probability of continuous sample observations, is commonly used for SEM. 
We used AMOS (SPSS, IBM, Inc.) structural equation modeling software to conduct SEM to estimate a complex set of causal relationships between burn severity, topographic variables, and red pine trees. Figure 2 illustrates the hypothesized model for initial estimation in this study. In the hypothesized model, slope and elevation were considered as exogenous variables and SRI, TWI, and percentage of red pine trees were entered as endogenous variables. Thus, slope and elevation can have both direct impacts on burn severity and indirect impacts on burn severity through SRI, TWI, and the percentage of red pine trees. In the model, SRI, TWI, and the percentage of red pine trees were hypothesized to be affected by slope and elevation and, at the same time, to affect burn severity. Standardized path coefficients were used to compare the relative magnitudes of predictors on target variables $(p<0.05)$. To estimate SEM, we used the bootstrapping method, which generates repeated estimates of the indirect effects. Using this method, multiple mediators were tested simultaneously, and indirect effects were assessed through 95\% bias-corrected confidence intervals. Finally, we compared the results of the SEM path analysis with the results of linear regression.

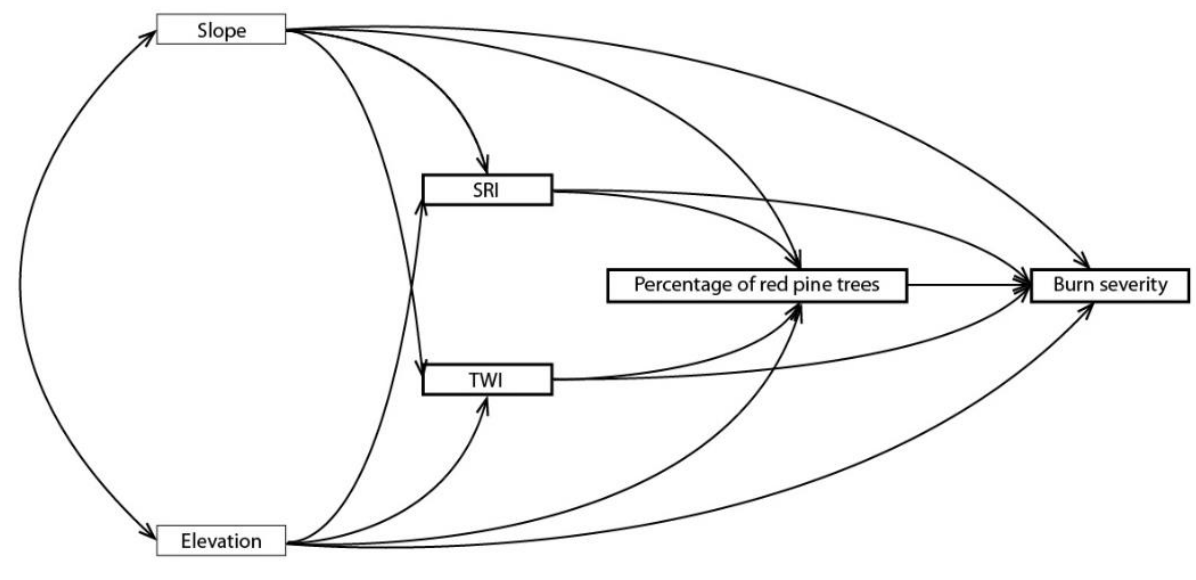

\begin{abstract}
$\square$ Endogenous variables
Figure 2. Hypothesized structural equation model. The hypothesized model indicates that slope and elevation have direct and indirect impacts on burn severity. They influence SRI, TWI, and the percentage of red pine trees, which have significant effects of the degree of burn severity.
\end{abstract}

\title{
2.6. Testing the Goodness of Fit of the Estimated SEM
}

A number of indices have been used to test the goodness of fit of an estimated SEM. The $\chi^{2}$ test is one of the commonly used indicators, but it is known to be sensitive to sample size [51], so some supplementary measures have been developed [52,53]. In this study, we used several criteria suggested in previous studies to test the model fit, including the goodness-of-fit index (GFI > 0.9), adjusted goodness-of-fit index (AGFI $>0.8$ ), comparative fit index (CFI $>0.9$ ), root mean square residuals (RMSR $<0.1$ ), root mean square error of approximation (RMSEA $<0.6$ ), normed fit index (NFI $>0.9$ ), and parsimony normed fit index (PNFI > 0.9) [53].

\section{Results}

\subsection{Profile of Variables and Their Relationships}

Complex topographic characteristics and great variations of SRI, TWI, the percent of red pine trees, and burn severity over space have been well documented in previous studies (e.g., [22,23,25]). Descriptive statistics demonstrate considerable variations in slope and elevation, suggesting complex topographic characteristics of the site. Specifically, slope ranges from $0.05^{\circ}$ to $28.341^{\circ}$ and has a mean value of $15.283^{\circ}$. Elevation ranges from $0 \mathrm{~m}$ to $849.5 \mathrm{~m}$ and has a mean value of $254.86 \mathrm{~m}$. High standard 
deviations of slope and elevation suggest great spatial variance of these variables. Accordingly, SRI has a wide range of 0.67 to 1.04 , with a mean value of 0.88 . TWI ranges from 1.24 to 5.67 , with a mean value of 2.46 . The percentage of red pine trees ranges from 0 to $100 \%$, with a mean value of $58.24 \%$, suggesting a very selective and aggregated distribution of red pine trees within the study areas. The mean value of the percentage of red pine trees within grid cells was 3.88 and the range was 1.5 to 5.73 (Table 1). According to a previous study [33], the burn severity was likely low in grid cells with low elevation $(r=-0.25)$ and low TWI $(r=-0.15)$. On the contrary, the burn severity was likely high in grid cells dominated by red pine trees $(r=0.47)$. A strong positive association between slope and elevation was observed $(r=0.69)$, suggesting that the mean slope was steep in cell grids in high elevation areas. Additionally, grid cells in high elevation areas were likely have fewer pine trees $(r=-0.42)$. TWI showed relatively strong associations with elevation $(r=-0.57)$ and slope $(r=-0.65)$ compared with the associations between SRI and elevation $(r=-0.14)$ and slope $(r=-0.37)$.

Table 1. Profile of the variables including unit, range, minimum, maximum, median, and mean. The considerable variance in slope and elevation suggests the geographical complexity of the study site. The great variance of the percentage of red pine trees indicates an aggregated distribution of red pine trees over space.

\begin{tabular}{cccccc}
\hline Variable & Unit & Min & Max & Median & Mean (SD) \\
\hline Slope & $\circ$ & 0.05 & 28.34 & 15.62 & $15.28(5.56)$ \\
Elevation & meter & 0.00 & 849.50 & 197.28 & $254.86(204.73)$ \\
SRI & unitless & 0.67 & 1.04 & 0.89 & $0.88(0.07)$ \\
TWI & unitless & 1.24 & 5.67 & 2.41 & $2.46(0.62)$ \\
\% red pine & $\%$ & 0.00 & 100 & 64.62 & $58.24(35.09)$ \\
Burn severity & 6 classes & 1.50 & 5.73 & 3.87 & $3.88(0.67)$ \\
\hline \multicolumn{7}{c}{$n=802}$. \\
\end{tabular}

\subsection{Multiple Linear Regression}

The estimated linear regression model for burn severity indicated that elevation $(b=-0.001$, $\beta=-0.27, p<0.01)$ and TWI $(b=-0.305, \beta=-0.29, p<0.01)$ could reduce the degree of burn severity, while the percentage of pine trees $(b=0.007, \beta=0.34, p<0.01)$ could amplify burn severity. However, slope and SRI did not appear to have significant effects on burn severity $(p<0.05)$ and were removed from the estimated model. The estimated linear regression model was able to explain about $27 \%$ of the variance in burn severity (A. R-square $=0.266$ ). The $F$-value of the estimated model was $97.64(p<0.01)$ (Table 2). The linear model for burn severity $\left(\mathrm{LM}_{\mathrm{bs}}\right)$ with elevation, TWI, and percentage of red pine trees is shown as Equation (1) below:

$$
\mathrm{LM}_{\mathrm{bs}}=4.42+(-0.001 \times \text { elevation })+(-0.305 \times \mathrm{TWI})+(0.007 \times \% \text { red pine })
$$

\subsection{Estimated Structural Equation Model}

In the hypothesized model, there were two exogenous variables-elevation and slope-and these were covariate variables. The model also included three endogenous variables (i.e., SRI, TWI, \% of red pine trees) and one dependent variable (burn severity). We estimated the initial structural equation model for burn severity with the two exogenous variables and three endogenous variables in SPSS AMOS. In the estimated initial model (Figure 3$)$, slope showed negative effects on SRI $(b=-0.007$, $\beta=-0.519)$ and TWI $(b=-0.056, \beta=-0.496)$ and a positive effect on the percentage of red pine trees $(b=1.641, \beta=0.260)$. However, the direct effect of slope on burn severity was not significant at the $95 \%$ confidential level. Elevation appeared to have a positive effect on SRI ( $b=0.0001, \beta=0.216)$ and negative effects on TWI $(b=-0.001, \beta=-0.228)$ and the percentage of red pine $(b=-0.113$, $\beta=-0.774)$. Unlike slope, elevation showed a direct negative effect on burn severity $(b=-0.001$, $\beta=-0.261)$. Thus, SRI was decreased by slope and increased by elevation, while TWI was decreased 
by both slope and elevation. Irrespective of sign, the standardized coefficients suggested that SRI and TWI values were more strongly affected by slope than elevation.

Table 2. Estimated regression results for burn severity. Standard errors are reported in parentheses. The estimated model explained about $27 \%$ of the variance of burn severity. In this model, the percentage of red pine trees increases the degree of burn severity, whereas elevation and TWI decrease burn severity.

\begin{tabular}{|c|c|c|c|}
\hline \multirow{2}{*}{ Variable } & \multicolumn{2}{|c|}{ Coefficient } & \multirow{2}{*}{$t$-Value } \\
\hline & $\mathbf{b}$ & $\beta$ & \\
\hline Constant & 4.42 & - & $28.84^{* *}$ \\
\hline Elevation & $-0.001^{* *}$ & -0.26 & $-6.06^{* *}$ \\
\hline TWI & $-0.305^{* *}$ & -0.28 & $-7.16^{* *}$ \\
\hline$\%$ Red pine trees & $0.007^{* *}$ & 0.34 & $9.52 * *$ \\
\hline$F$-value & \multicolumn{3}{|c|}{$97.64^{* *}$} \\
\hline Adjusted R-squared & \multicolumn{3}{|c|}{0.266} \\
\hline
\end{tabular}
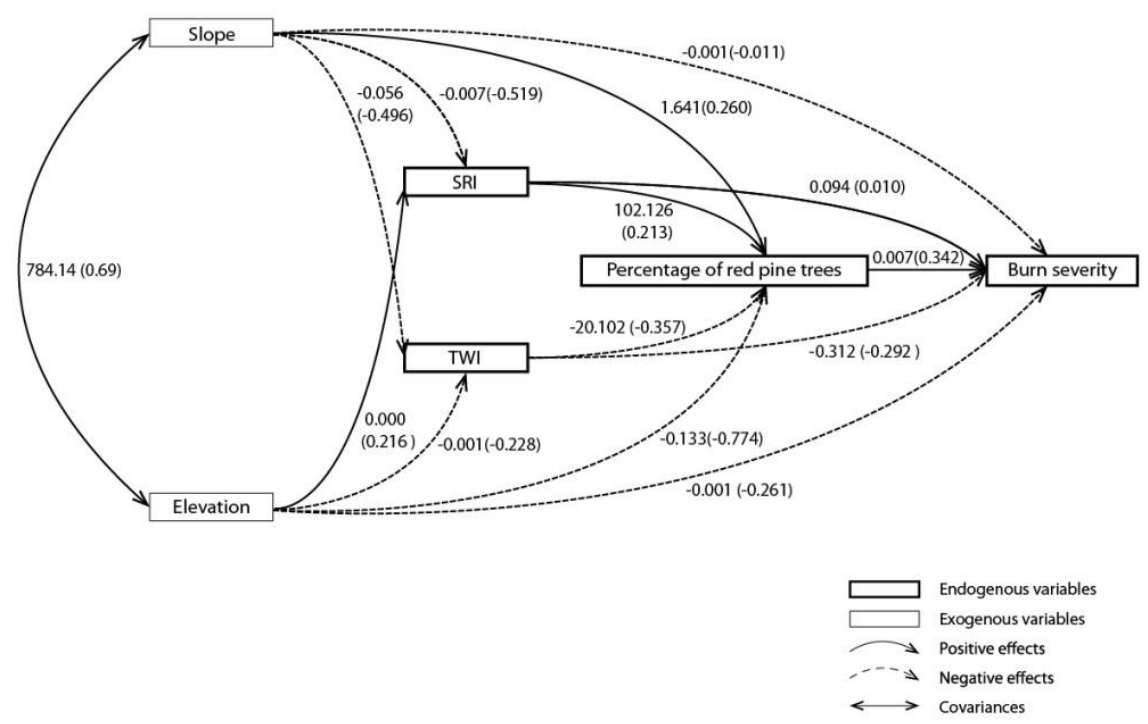

Figure 3. The estimated structural equation model (SEM). Slope and elevation appeared to have significant effects on SRI and TWI. The percentage of red pine trees was affected by slope, elevation, SRI and TWI. Elevation, TWI, and the percentage of red pine trees had impacts on burn severity. However, slope and SRI did not show significant effects on burn severity in the estimated SEM. Values in parentheses are standardized coefficients.

In the estimated model, SRI showed a positive effect on the percentage of red pine trees $(b=102.126, \beta=-0.213)$ but no significant effect on burn severity. It was hypothesized that TWI had impacts on the percentage of red pine trees and burn severity, as shown in the hypothesized model. TWI negatively affected the percentage of red pine $(b=-20.102, \beta=-0.357)$ and burn severity $(b=-0.312, \beta=-0.292)$. In the hypothesized model, the percentage of red pine trees was affected by slope, elevation, SRI, and TWI. The estimated initial model suggested that the percentage of red pine trees would be positively affected by slope and SRI and negatively influenced by elevation and TWI. In our hypothesized model, burn severity was affected by slope, elevation, SRI, TWI, and the percentage of red pine trees. The estimated SEM partially supported the hypothesized model. Specifically, burn severity was affected by elevation $(b=-0.001, \beta=-0.261)$, TWI $(b=-0.312, \beta=-0.292)$, and the percentage of red pine trees $(b=0.007, \beta=0.342)$. However, slope and SRI did not show any significant 
effects on burn severity (Table 3). This result was almost identical with the result of the linear regression analysis in Table 2, which showed significant effects of elevation, TWI, and the percentage of red pine trees and no significant effects of slope and SRI. Exclusion of the paths that showed no significance (i.e., from slope to SRI, from SRI to burn severity) at the significance level (Table 3) resulted in a simplified structural equation model for burn severity with slope, elevation, SRI, TWI, and percentage of red pine trees (Figure 4). Despite eliminating insignificant paths from the initial model, there were not many changes in the coefficients of remaining paths. The SEMs of the initial model (Figure 3) and the reduced model (Figure 4) were almost identical. There were only a few changes in coefficients of the paths from red pine trees to burn severity, TWI to burn severity, and elevation to burn severity. However, the changes were modest at best.

Table 3. Estimated initial SEM. Almost all paths in the hypothesized model were verified in the estimated SEM. However, slope and SRI did not show significant effects on burn severity.

\begin{tabular}{ccccccc}
\hline & Path & & Coefficient & S.E. & C.R. & $P$ \\
\hline SRI & $\leftarrow$ & Slope & -0.007 & 0.001 & -11.617 & $* * *$ \\
SRI & $\leftarrow$ & Elevation & 0.000 & 0.000 & 4.831 & $* * *$ \\
TWI & $\leftarrow$ & Slope & -0.056 & 0.004 & -13.741 & $* * *$ \\
TWI & $\leftarrow$ & Elevation & -0.001 & 0.000 & -6.318 & $* * *$ \\
Red Pine & $\leftarrow$ & Slope & 1.641 & 0.296 & 5.543 & $* * *$ \\
Red Pine & $\leftarrow$ & Elevation & -0.133 & 0.007 & -18.815 & $* * *$ \\
Red Pine & $\leftarrow$ & SRI & 102.126 & 15.014 & 6.802 & $* * *$ \\
Red Pine & $\leftarrow$ & TWI & -20.102 & 2.183 & -9.209 & $* * *$ \\
BS & $\leftarrow$ & TWI & -0.312 & 0.046 & -6.780 & $* * *$ \\
BS & $\leftarrow$ & Elevation & -0.001 & 0.000 & -5.019 & $* * *$ \\
BS & $\leftarrow$ & Red pine & 0.007 & 0.001 & 9.185 & $* * *$ \\
BS & $\leftarrow$ & Slope & -0.001 & 0.006 & -0.209 & 0.835 \\
BS & $\leftarrow$ & SRI & 0.094 & 0.310 & 0.302 & 0.763 \\
\hline
\end{tabular}
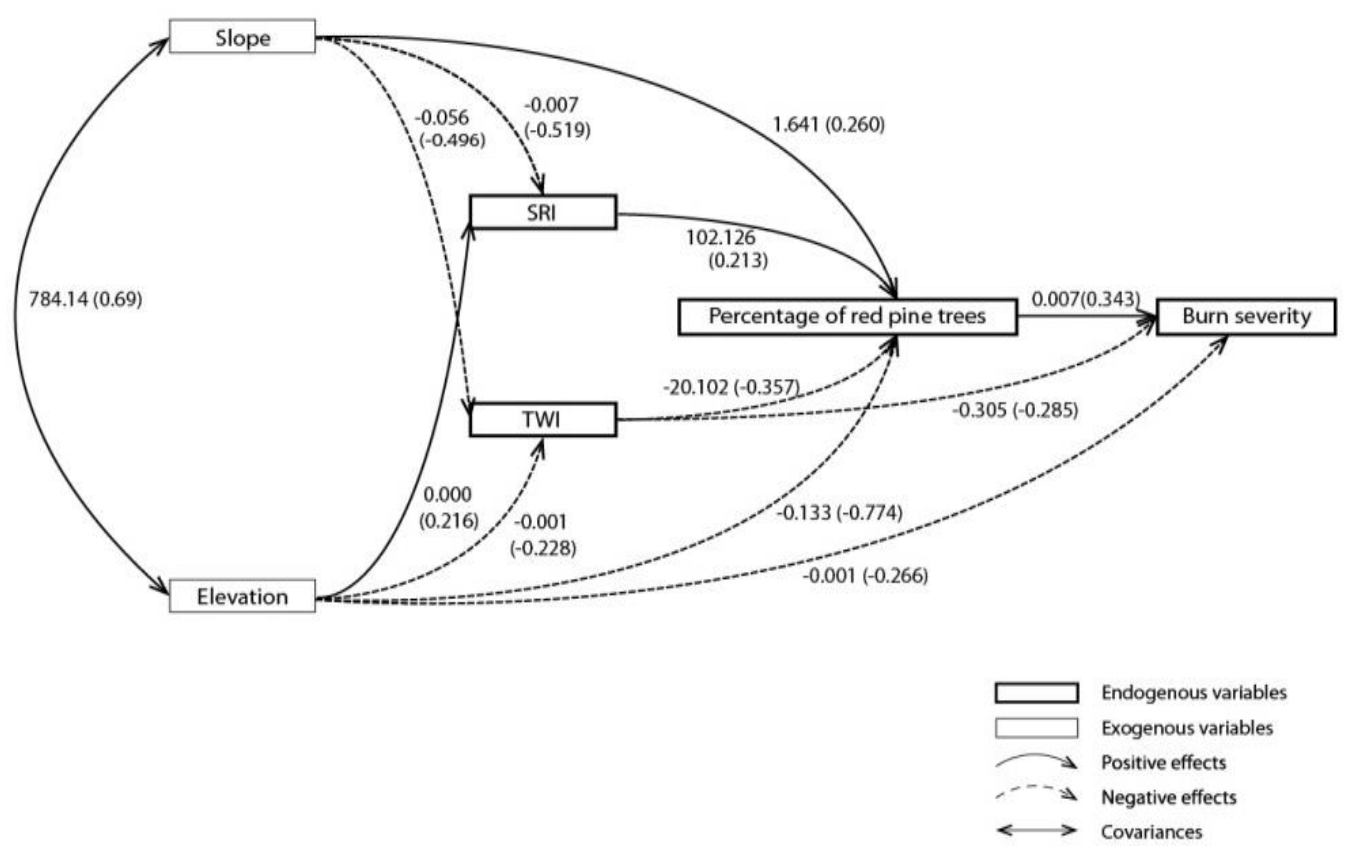

Figure 4. The final structural equation model for burn severity with topographic characteristics and red pine trees. Paths from slope and SRI to burn severity were not significant and were eliminated from the initial model. Values in parentheses are standardized coefficients. 


\subsection{Goodness of Fit}

The initial model provided a good fit to the observed data. The $\chi^{2}$ value was 0.697 , which was not significant $(p>0.05)$, indicating that there was no significant difference between the observed and implied variance/covariance matrix. The other goodness-of-fit indices also indicated a good fit within the accepted exhortation levels: goodness-of-fit index $(\mathrm{GFI})=1.000$, adjusted goodness-of-fit index $(\mathrm{AGFI})=0.999$, comparative fit index $(\mathrm{CFI})=1.000$, root mean square error of approximation $($ RMSEA $)=0.000$, root mean square residual $($ RMR $)=0.044$, normed fit index $(\mathrm{NFI})=1.000$, and parsimony normed fit index $(\mathrm{PNFI})=0.067$. The root mean square residuals $(\mathrm{RMSR})=0.38$. Despite the fact that the PNFI and RMSR values did not satisfy the suggested criteria, the overall goodness of fit of the estimated model seemed to be good enough (Table 4).

Table 4. Summary of initial and final model fit. Most of the recommended indices of the estimated model [53] were in the acceptable range, with the exceptions of RMSR and PNFI.

\begin{tabular}{cccc}
\hline Goodness-of-Fit Index & Recommended Value & Initial Model & Final Model \\
\hline$\chi^{2}$ & Non-significant at $p<0.05$ & 0.69 & 0.37 \\
Goodness-of-fit index (GFI) & $>0.90$ & 1.00 & 1.00 \\
Adjusted goodness-of-fit index (AGFI) & $>0.80$ & 0.99 & 0.99 \\
Comparative fit index (CFI) & $>0.90$ & 1.00 & 1.00 \\
Root mean square residuals (RMSR) & $<0.10$ & 0.38 & 0.38 \\
Root mean square error of approximation (RMSEA) & $<0.08$ & 0.00 & 0.00 \\
Normed fit index (NFI) & $>0.90$ & 1.00 & 1.00 \\
Parsimony normed fit index (PNFI) & $>0.60$ & 0.07 & 0.20 \\
\hline
\end{tabular}

\section{Discussion}

SEM has been shown to be suited to exploring the mediation effects of intermediate variables on the causal relationships of predictors with a dependent variable. SEM does not simply estimate the direct effects that are often implicitly considered in an OLS analysis. Instead, it decomposes the effects into direct effects and indirect effects acting through intermediate variables in the system. In this context, the total effect could be significant, even if each of the direct or (and) indirect effects are not significant.

The estimated SEM strongly indicated that the effects of topographic characteristics and susceptible fuel on burn severity might be far more complex than we initially anticipated. In the fire literature, the relationships of elevation and slope with burn severity have been portrayed somewhat contradictorily. Positive relationships of elevation and slope with burn severity have been reported in a number of studies (e.g., [54-56]). On the contrary, other studies have reported a negative effect of elevation on burn severity (e.g., [16,39]) due in part to cooler temperatures and higher humidity [23]. Some of the possible reasons for these controversial results in previous studies and in this study are complex interactions among the fire triangle (i.e., fuel, topography, and fire weather) during a fire event $[4,23,47-50,55]$, nonlinear effects $[23,25,57]$, and spatially varying effects of topographic variables on burn severity [22].

Equation (2) showed the method for computing the indirect effects of elevation on burn severity with standardized coefficients. In Equation (2), the indirect effects of elevation on burn severity can be understood as the sum of four indirect effects, the through SRI effect, through TWI effect, through TWI-red pine effect, and through red pine effect. The sum of the estimated standardized indirect effects of elevation on burn severity was -0.157 (Table 5 ). The total effect of elevation on burn severity was the sum of the direct effect and indirect effect (Equation (3)). From this perspective, the effect of elevation on burn severity could be decreased by both the direct effect of elevation and the indirect effects derived from interactions of elevation with slope, SRI, TWI, and the percentage of red pine trees. The estimated linear regression model (Equation (1)) suggested a negative (direct) effect of elevation on burn severity. However, the estimated SEM (Figure 4, Equation (2)) strongly suggested that this effect could be lowered further by TWI. On the contrary, SRI and the percentage of red pine trees could increase burn severity indirectly. 
Table 5. Summary of direct and indirect effects of variables on burn severity and their $95 \%$ confidence intervals. All of the standardized path coefficients of the variables indicated that elevation and TWI had both direct and indirect effects on burn severity, while slope and SRI appeared to have only indirect effects. The percentage of red pine trees seemed to have only a direct effect.

\begin{tabular}{|c|c|c|c|c|c|}
\hline \multirow{2}{*}{ Variable } & \multirow{2}{*}{$\begin{array}{l}\text { Effect Type (on } \\
\text { Burn Severity) }\end{array}$} & \multirow{2}{*}{$\begin{array}{c}\text { Path } \\
\text { Coefficient }(\beta)\end{array}$} & \multicolumn{2}{|c|}{$95 \%$ CI } & \multirow{2}{*}{$p$} \\
\hline & & & Lower & Upper & \\
\hline Elevation & Direct & -0.266 & & & \\
\hline TWI & Direct & -0.285 & & & \\
\hline Pine trees & Direct & 0.343 & & & \\
\hline Elevation & Indirect & -0.157 & -0.223 & -0.094 & $0.002 * *$ \\
\hline Slope & Indirect & 0.253 & 0.199 & 0.317 & 0.001 ** \\
\hline TWI & Indirect & -0.123 & -0.162 & -0.09 & $0.001^{* *}$ \\
\hline SRI & Indirect & 0.073 & 0.049 & 0.105 & $0.001^{* *}$ \\
\hline
\end{tabular}

$$
\begin{gathered}
\text { Indirect effect } \text { televation on bs }=\text { Effect } 1 \beta_{\text {through SRI \& pine }}=[(0.216 \times 0.213 \times 0.343)] \\
\quad+\text { Effect } 2 \beta_{\text {through TWI }}=[(-0.228 \times-0.285)]+\text { Effect } 3 \beta_{\text {through TWI \& pine }} \\
=[(-0.228 \times-0.357 \times 0.343)]+\text { Effect } 4\left(\beta_{\text {through pine }}\right)=[(-0.774 \times 0.343)]
\end{gathered}
$$

Total effect elevation on bs $=$ Direct effect $(\beta=-0.266)+$ Indirect effects $(\beta=-0.157)$

Slope did not appear as a significant variable affecting burn severity directly in the estimated linear model (Table 2, Equation (1)). Figure 4 supports the results of the linear regression analysis, indicating no direct effects of slope on burn severity. However, slope showed indirect effects on burn severity through SRI, through TWI, through SRI-red pine, through TWI-red pine, and through red pine (Figure 4 and Table 5). The sum of the indirect effects and the total effect of slope on burn severity ( $\beta=0.253$ ) could be computed by Equation (4). In this case, Equations (4) and (5) were identical because the direct effect of slope was zero. However, the indirect effect of slope in Equation (5) and Table 5 suggested that there was a total positive effect of slope on burn severity. Despite the fact that no significant effect of slope on burn severity was observed in the linear regression model, the estimated SEM identified a significant positive total effect of slope on burn severity.

$$
\begin{aligned}
& \text { Indirect effect } \text { slope on bs }=\text { Effect } 1\left(\beta_{\text {through SRI\&pine }}\right)=[(-0.519 \times 0.213 \times 0.343)] \\
& + \text { Effect } 2\left(\beta_{\text {through TWI }}\right)=[(-0.496 \times-0.285)]+\text { Effect } 3\left(\beta_{\text {through TWI } \& \text { pine }}\right)= \\
& {[(-0.496 \times-0.357 \times 0.343)]+\text { Effect } 4\left(\beta_{\text {through pine }}\right)=[(0.26 \times 0.343)]} \\
& \text { Total effect } \text { slope on bs }=\text { Direct effect }(\beta=0)+\text { Indirect effects }(\beta=0.253)
\end{aligned}
$$

Similarly, SRI did not show a significant direct effect on burn severity. However, a modest but significant indirect effect (i.e., through the percentage of red pine trees) of SRI ( $\beta=0.073)$ on burn severity was observed. Additionally, TWI was shown to have both direct $(\beta=-0.285)$ and indirect $(\beta=-0.123$ ) effects on burn severity (Table 5$)$. The percentage of red pine trees appeared to have only a direct effect on burn severity $(\beta=0.343)$.

Indirect effects, as reported in this study, might add another dimension to the complex relationships between topographic characteristics and burn severity. As numerous studies [23,54-56] discussed, topographic variables play a significant role not only during the burning event but also during the long-term pre-fire conditioning of fuels (e.g., availability of susceptible fuels, long-term moisture, composition/configuration of fuels, accumulation of ground fuels, etc.). The indirect effect of topographic variables might be associated with the long-term pre-fire conditions of fuels, while the direct effect might be related with interactions among fuels and fire weather during the burning event. In sum, the results of this study and those of previous studies provide reasons for caution with regard to over-simplification of the relationships between topographic characteristics and burn 
severity. However, the SEM estimated in this study reinforced the strong tie between susceptible forest cover type and burn severity that has been reported in numerous previous studies irrespective of geographic location.

\section{Conclusions}

Concern about the direct and indirect effects of topographic variables on burn severity has been expressed in the literature. Direct effects can be regarded as the physical settings of a fire event, whereas indirect effects can be considered to be related to the pre-fire conditions of fuel, such as composition, configuration, density, average stand diameter, and long-term moisture. In this study, we were able to distinguish direct effects and indirect effects of topographic characteristics by using the structural equation model (SEM), which was able to decompose the effects of topographic variables into direct and indirect types. From the estimated SEM, we found that elevation and topographic wetness index (TWI) had both direct and indirect effects on burn severity. However, slope and solar radiation index (SRI) appeared to have only indirect effects on burn severity, which could not be captured by the conventional linear regression model.

The findings of previous studies and this study strongly suggest that over-simplification of the relationships between topographic characteristics and burn severity might lead to false conceptions about the effects of topographic variables on burn severity due to indirect, non-linear, and spatially varying effects of topographic variables on burn severity. Additionally, the results of this study and those of previous studies strongly suggest that conventional ordinary least square methods such as correlation and linear regression cannot effectively capture these complex effects of topographic characteristics on burn severity. Inconsistent effects of topographic characteristics on burn severity have been reported in the fire literature, and we found that the effects of topographic characteristics (e.g., elevation, slope, SRI, TWI) on burn severity are far more complex than previously recognized.

Nonetheless, the effect of susceptible forest cover on burn severity was consistent. Irrespective of topographic complexity, Japanese red pine appeared to increase burn severity in Korean forests. In this context, forest management and silviculture should pay closer attention to susceptible fuels than to topographic characteristics. In addition, consideration of the topographic characteristics of target areas might be a useful supplemental approach in forest management and silviculture. In practical perspective, it might be an effective approach to consider the topographic characteristics and distributions of susceptible forest cover together. For example, one needs to identify areas with high SRI values and those that are covered by susceptible forest cover. Burn severity in areas covered by susceptible forest cover (e.g., red pine trees) might not be higher than expected if TWI values were high, because such topographic conditions could increase the moisture content of fuels. These approaches may help forest managers in place-specific prioritization of areas requiring more/less intensive fuel treatments, such as prescribed burning, mechanical thinning, or placing breaks. Thus, fuel treatments of susceptible forest cover without consideration of topographic characteristics may not be efficient in lowering burn severity. It was noteworthy that slope and SRI increased the percent of susceptible forest cover (i.e., Japanese red pine), while elevation and TWI had the opposite effect in the study areas. However, the roles of topographic characteristics in the distribution of susceptible forest cover may depend on the types of susceptible forest cover. Different types of susceptible forest cover may prefer totally different topographic conditions.

The spatial scale of this study was $500 \mathrm{~m}$. However, investigating the direct and indirect effects of topographic variables at a broader scale might have led to somewhat different conclusions. Subsequent studies may need to consider different spatial scales or fire site scales. Due to a lack of weather data, we were not able to integrate weather factors into the modeling of direct and indirect effects of topographic variables on burn severity. Considering interactions of topographic characteristics with fuels and weather factors might provide a more sophisticated result that could facilitate understanding of the true nature of effects of topographic characteristics on burn severity and their relative importance within the forest fire triangle. 
Author Contributions: All authors contributed to the intellectual content of this paper. The first author, E.-J.K., developed the research design and gathered data, including satellite images and GIS data. She was also responsible for estimating the structural equation model. The corresponding author, S.-W.L., wrote the manuscript and contributed to the interpretation of the statistics.

Funding: This research received no external funding.

Acknowledgments: The authors thank the National Institute of Forest Science (NIFS) for providing satellite images and field data of burn severity in the study areas.

Conflicts of Interest: The authors declare no conflict of interest.

\section{References}

1. Sampaio, E.D.S.; Salcedo, I.H.; Kauffman, J.B. Effect of different fire severities on coppicing of caatinga vegetation in Serra Talhada, PE, Brazil. Biotropica 1993, 25, 452-460. [CrossRef]

2. Covington, W.W.; Moore, M.M. Postsettlement changes in natural fire regimes and forest structure: Ecological restoration of old-growth ponderosa pine forests. J. Sustain. For. 1994, 2, 153-181. [CrossRef]

3. Morgan, P.; Hardy, C.C.; Swetnam, T.W.; Rollins, M.G.; Long, D.G. Mapping fire regimes across time and space: Understanding coarse and fine-scale fire patterns. Int. J. Wildland Fire 2001, 10, 329-342. [CrossRef]

4. Lentile, L.B.; Smith, F.W.; Shepperd, W.D. Influence of topography and forest structure on patterns of mixed severity fire in ponderosa pine forests of the South Dakota Black Hills, USA. Int. J. Wildland Fire 2006, 15, 557-566. [CrossRef]

5. Fontaine, J.B.; Kennedy, P.L. Meta-analysis of avian and small-mammal response to fire severity and fire surrogate treatments in US fire-prone forests. Ecol. Appl. 2012, 22, 1547-1561. [CrossRef] [PubMed]

6. Cawson, J.G.; Sheridan, G.J.; Smith, H.G.; Lane, P.N.J. Effects of fire severity and burn patchiness on hillslope-scale surface runoff, erosion and hydrologic connectivity in a prescribed burn. For. Ecol. Manag. 2013, 310, 219-233. [CrossRef]

7. Mehdi, H.; Ali, S.; Ali, M.; Mostafa, A. Effects of different fire severity levels on soil chemical and physical properties in Zagros forests of western Iran. Folia For. Pol. Ser. A 2012, 54, 241-250.

8. Wimberly, M.C.; Reilly, M.J. Assessment of fire severity and species diversity in the southern Appalachians using Landsat TM and ETM+ imagery. Remote Sens. Environ. 2007, 108, 189-197. [CrossRef]

9. Wang, C.; Gower, S.T.; Wang, Y.; Zhao, H.; Yan, P.; Bond-Lamberty, B.P. The influence of fire on carbon distribution and net primary production of boreal Larix gmelinii forests in north-eastern China. Glob. Chang. Biol. 2001, 7, 719-730. [CrossRef]

10. Dayamba, S.D.; Tigabu, M.; Sawadogo, L.; Oden, P.C. Seed germination of herbaceous and woody species of the Sudanian savanna-woodland in response to heat shock and smoke. For. Ecol. Manag. 2008, 256, 462-470. [CrossRef]

11. Westlind, D.J.; Kerns, B.K. Long-term effects of burn season and frequency on ponderosa pine forest fuels and seedlings. Fire Ecol. 2017, 13. [CrossRef]

12. Fernández, C.; Vega, J.A.; Vieira, D.C.S. Assessing soil erosion after fire and rehabilitation treatments in NW Spain: Performance of RUSLE and revised Morgan-Morgan-Finney models. Land Degrad. Dev. 2010, 21, 58-67. [CrossRef]

13. Turner, M.G.; Hargrove, W.W.; Gardner, R.H.; Romme, W.H. Effects of fire on landscape heterogeneity in Yellowstone National Park, Wyoming. J. Veg. Sci. 1994, 5, 731-742. [CrossRef]

14. Jain, T.B.; Graham, R.T. The relation between tree burn severity and forest structure in the Rocky Mountains. In Restoring Fire-adapted Ecosystems: Proceedings of the 2005 National Silviculture Workshop. USDA Forest Service Gen. Tech. Rep PSW-GTR-203; Pacific Southwest Research Station, Forest Service, US Department of Agriculture: Albany, CA, USA, 2005; pp. 213-250.

15. Pinard, M.A.; Putz, F.E.; Licona, J.C. Tree mortality and vine proliferation following a wildfire in a subhumid tropical forest in eastern Bolivia. For. Ecol. Manag. 1999, 116, 247-252. [CrossRef]

16. Van Mantgem, P.J.; Nesmith, J.C.; Keifer, M.; Brooks, M. Tree mortality patterns following prescribed fire for Pinus and Abies across the southwestern United States. For. Ecol. Manag. 2013, 289, 463-469. [CrossRef]

17. Johnstone, J.F.; Chapin, F.S. Effects of soil burn severity on post-fire tree recruitment in boreal forest. Ecosystems 2006, 9, 14-31. [CrossRef] 
18. Walker, L.R.; Boneta, W. Plant and soil responses to fire on a fern-covered landslide in Puerto Rico. J. Trop. Ecol. 1995, 11, 473-479. [CrossRef]

19. Crotteau, J.S.; Varner, J.M., III; Ritchie, M.W. Post-fire regeneration across a fire severity gradient in the southern Cascades. For. Ecol. Manag. 2013, 287, 103-112. [CrossRef]

20. Lee, J.M.; Lee, S.W.; Lim, J.H.; Won, M.S.; Lee, H.S. Effects of heterogeneity of pre-fire forests and vegetation burn severity on short-term post-fire vegetation density and regeneration in Samcheok, Korea. Landsc. Ecol. Eng. 2014, 10, 215-228. [CrossRef]

21. Lee, B.; Won, M.S.; Lee, Y.; Lee, M.B. Crown fuel characteristics and carbon emission from Japanese red pine stands burned by crown fire in Mt. Palgong, South Korea. J. Mt. Sci. 2012, 9, 656-664. [CrossRef]

22. Lee, H.J.; Kim, E.J.; Lee, S.W. Examining spatial variation in the effects of Japanese red pine (Pinus densiflora) on burn severity using geographically weighted regression. Sustainability 2017, 9, 804. [CrossRef]

23. Lee, H.J.; Choi, Y.E.; Lee, S.W. Complex relationships of the effects of topographic characteristics and susceptible tree cover on burn severity. Sustainability 2018, 10, 295. [CrossRef]

24. Korea Forest Service (KFS). Fires in Eastern Regions; Korea Forest Service: Daejoen, Korea, 2001; Volume 1, pp. 33-36.

25. Lee, S.W.; Lee, M.B.; Lee, Y.G.; Won, M.S.; Kim, J.J.; Hong, S.K. Relationship between landscape structure and burn severity at the landscape and class levels in Samchuck, South Korea. For. Ecol. Manag. 2009, 258, 1594-1604. [CrossRef]

26. Tian, H.; Chen, G.; Liu, M.; Zhang, C.; Sun, G.; Lu, C.; Xu, X.; Ren, W.; Pan, S.; Chappelka, A. Model estimates of net primary productivity, evapotranspiration, and water use efficiency in the terrestrial ecosystems of the southern United States during 1895-2007. For. Ecol. Manag. 2010, 259, 1311-1327. [CrossRef]

27. Liu, Y.; Goodrick, S.L.; Stanturf, J.A. Future US wildfire potential trends projected using a dynamically downscaled climate change scenario. For. Ecol. Manag. 2013, 294, 120-135. [CrossRef]

28. O'Connor, C.D.; Falk, D.A.; Lynch, A.M.; Swetnam, T.W. Fire severity, size, and climate associations diverge from historical precedent along an ecological gradient in the Pinaleño Mountains, Arizona, USA. For. Ecol. Manag. 2014, 329, 264-278. [CrossRef]

29. Nelson, R.M., Jr. An effective wind speed for models of fire spread. Int. J. Wildland Fire 2002, 11, $153-161$. [CrossRef]

30. Sung, J.H.; Jo, J.H.; Lee, Y.G.; Won, M.S.; Kim, S.D. Changes in physiological characteristics and regeneration of damaged trees. In Ecological Changes in Burned Forests; Lee, M.-B., Ed.; Korea Forest Research Institute: Seoul, Korea, 2007; pp. 53-112. (In Korean)

31. Collins, B.; Skinner, C. Fire and fuels. In Science Synthesis to Support Socioecological Resilience in the Sierra Nevada and Southern Cascade Range; Gen. Tech. Rep. PSW-GTR-247; Long, J.W., Quinn-Davidon, L., Skinner, C.N., Eds.; USDA Forest Service, Pacific Southwest Research Station: Albany, CA, USA, 2014; pp. 143-172.

32. Collins, B.M.; Lydersen, J.M.; Fry, D.L.; Wilkin, K.; Moody, T.; Stephens, S.L. Variability in vegetation and surface fuels across mixed-conifer-dominated landscapes with over 40 years of natural fire. For. Ecol. Manag. 2016, 381, 74-83. [CrossRef]

33. Harris, L.; Taylor, A.H. Topography, fuels, and fire exclusion drive fire severity of the rim fire in an old-growth mixed-conifer forest, Yosemite National Park, USA. Ecosystems 2015, 18, 1192-1208. [CrossRef]

34. Hessburg, P.F.; Churchill, D.J.; Larson, A.J.; Haugo, R.D.; Miller, C.; Spies, T.A.; North, M.P.; Povak, N.A.; Belote, R.T.; Singleton, P.H. Restoring fire-prone inland Pacific landscapes: Seven core principles. Landsc. Ecol. 2015, 30, 1805-1835. [CrossRef]

35. Lydersen, J.; North, M. Topographic variation in structure of mixed-conifer forests under an active-fire regime. Ecosystems 2012, 15, 1134-1146. [CrossRef]

36. Korb, J.E.; Fulé, P.Z.; Wu, R. Variability of warm/dry mixed conifer forests in Southwestern Colorado, USA: Implications for ecological restoration. For. Ecol. Manag. 2013, 304, 182-191. [CrossRef]

37. Miller, J.D.; Thode, A.E. Quantifying burn severity in a heterogeneous landscape with a relative version of the delta Normalized Burn Ratio (dNBR). Remote Sens. Environ. 2007, 109, 66-80. [CrossRef]

38. Thompson, J.R.; Spies, T.A. Vegetation and weather explain variation in crown damage within a large mixed-severity wildfire. For. Ecol. Manag. 2009, 258, 1684-1694. [CrossRef]

39. McCune, B.; Keon, D. Equations for potential annual direct incident radiation and heat load. J. Veg. Sci. 2002, 13, 603-606. [CrossRef]

40. Gruber, S.; Peckham, S. Land-surface parameters and objects in hydrology. Dev. Soil Sci. 2009, 33, 171-194. 
41. Kopecký, M.; Č́žzová, Š. Using topographic wetness index in vegetation ecology: Does the algorithm matter? Appl. Veg. Sci. 2010, 13, 450-459. [CrossRef]

42. Epting, J.; Verbyla, D.; Sorbel, B. Evaluation of remotely sensed indices for assessing burn severity in interior Alaska using Landsat TM and ETM+. Remote Sens. Environ. 2005, 96, 328-339. [CrossRef]

43. Kumar, L.; Clarke, P.; Muñoz, C.; Knox, K. Mapping of fire severity and comparison of severity indices across vegetation types in Gibraltar Range National Park, Australia. Int. Arch. Photogramm. Remote Sens. Spat. Inf. Sci. 2008, 37, 1477-1482.

44. Murphy, K.A.; Reynolds, J.H.; Koltun, J.M. Evaluating the ability of the differenced Normalized Burn Ratio (dNBR) to predict ecologically significant burn severity in Alaskan boreal forests. Int. J. Wildland Fire 2008, 17, 490-499. [CrossRef]

45. Won, M.S.; Koo, K.S.; Lee, M.B.; Son, Y.M. Estimation of non- $\mathrm{CO}_{2}$ greenhouse gases emissions from biomass burning in the Samcheok large-fire area using Landsat TM imagery. Korean J. Agric. For. Meteorol. 2008, 10, 17-24. [CrossRef]

46. Remote Sensing Application Center. Burned Area Emergency Response (BAER) Imagery Support; Department of Agriculture Forest Service, Remote Sensing Applications Center: Salt Lake City, UT, USA, 2005. Available online: http:/ / www.fs.fed.us/eng/rsac/baer/ (accessed on 4 October 2016).

47. Linn, R.; Winterkamo, J.; Edminster, C.; Colman, J.J.; Smith, W.S. Coupled influence of topography and wind on wildland fire behavior. Int. J. Wildland Fire 2007, 16, 183-195. [CrossRef]

48. Forthofer, J.M.; Butler, B.W.; Shannon, K.S.; Finney, M.A.; Bradshaw, L.S.; Stratton, R. Predicting surface winds in complex terrain for use in fire spread models. In Proceedings of the Fifth Symposium on Fire and Forest Meteorology, Orlando, FL, USA, 16-20 November 2003.

49. Linn, R.; Winterkamp, J.; Colman, J.J.; Edminster, C.; Bailey, J.D. Modeling interactions between fire and atmosphere in discrete element fuel beds. Int. J. Wildland Fire 2005, 14, 37-48. [CrossRef]

50. Viegas, D.X. Slope and wind effects on fire propagation. Int. J. Wildland Fire 2004, 13, 143-156. [CrossRef]

51. Iacobucci, D. Structural equations modeling: Fit indices, sample size, and advanced topics. J. Consum. Psychol. 2010, 20, 90-98. [CrossRef]

52. Hu, L.T.; Bentler, P.M. Cutoff criteria for fit indexes in covariance structure analysis: Conventional criteria versus new alternatives. Struct. Equ. Model. Multidiscip. J. 1999, 6, 1-55. [CrossRef]

53. Hair, J.F.; Anderson, R.E.; Tatham, R.L.; Black, W.C. Multivariate Data Analysis; Pearson Education Limited: Edinburgh Gate, UK, 2010.

54. Fulé, P.Z.; Korb, J.E.; Wu, R. Changes in forest structure of a mixed conifer forest, southwestern Colorado, USA. For. Ecol. Manag. 2009, 258, 1200-1210. [CrossRef]

55. Finney, M.A.; McHugh, C.W.; Grenfell, I.C. Stand- and landscape-level effects of prescribed burning on two Arizona wildfires. Can. J. For. Res. 2005, 35, 1714-1722. [CrossRef]

56. Estes, B.L.; Knapp, E.E.; Skinner, C.N.; Miller, J.D.; Preisler, H.K. Factors influencing fire severity under moderate burning conditions in the Klamath Mountains, northern California, USA. Ecosphere 2017, 8, e01794. [CrossRef]

57. González, J.R.; Palahí, M.; Pukkala, T. Integrating fire risk considerations in forest management planning in Spain-A landscape level perspective. Landsc. Ecol. 2005, 20, 957-970. [CrossRef]

(C) 2018 by the authors. Licensee MDPI, Basel, Switzerland. This article is an open access article distributed under the terms and conditions of the Creative Commons Attribution (CC BY) license (http:/ / creativecommons.org/licenses/by/4.0/). 